\title{
日本語専攻生の対話型授業に対する捉え方 \\ 一中国の大学日本語専攻で行われた卒業論文支援の実践分析から一 \\ Japanese Majors’ Perception of the Dialogue-oriented Lesson: \\ An Analysis of the Graduation Thesis Instruction Practice in China
}

\section{楊 秀娥 \\ 中山大学}

\section{要旨}

本研究では、中国の大学における日本語専攻生が対話型授業をどのように捉えて いるのかについて分析した。中国の大学における日本語専攻生は、教師主導による 言語知識の伝授を主に受けてきており、対話型授業に対して抵抗感が強いと思われて いる。本研究では、筆者が中国のある大学日本語専攻で行った卒業論文支援の実践に 参加した学習者の事例から、日本語専攻生の対話型授業に対する捉え方を分析した。 教師一学習者間の対話において、学習者は、教師と対等な関係にあり、教師を傾聴者、 アドバイザーと捉えており、教師の話を批判的に吟味していた。そして、学習者は、 仲間の意見が大事であると考え、仲間との話し合いが不足していると反省していた。 また、教室内の教師一学習者間、学習者同士間の対話は、対話に直接参加しなかった 教室内のほかの学習者にも影響を与え、学習者の教室外における他者との対話を活性 化させ、さらに、修了した学習者の社会生活にもよい影響をもたらした。

キーワード :

日本語専攻教育、対話型授業、卒業論文支援、教師一学習者間の対話、学習者同士間の対話 


\section{日本語専攻生の対話型授業に対する捉え方 一中国の大学日本語専攻で行われた卒業論文支援の実践分析からー}

\section{楊 秀娥 中山大学}

\section{1. 研究背景と研究内容}

日本語専攻教育は、大学で日本語や日本文学、文化など「日本」について専攻し、 学士の学位を取得する学習者（以下、日本語専攻生）を対象に行う専門教育である。 中国における日本語専攻教育は、1999 年の大学学生募集定員の拡大とともにすさまじい 勢いで発展してきている。2014 年現在、中国全土 1145 校の大学のうち、506 校に日本語 専攻が設置されている（鐘・孫 2014）。日本語専攻教育は、今日まで日本語人材を多数 送り出し、日中間の経済・教育・外交などさまざまな分野に大きく貢献してきている。 一方、日本語教育においては、対話への関心が高まり、対話型授業が導入されてきて いるものの、中国の大学における日本語専攻教育においては、依然として教師主導に よる言語知識の伝授という傾向が強い。その結果の一つとして、本文の第 3 節で 述べるように、ほかの学科の学生より日本語専攻生の思考力が弱いという批判が もたらされた。

本研究は、教育理論と日本語教育で重視されつつある対話型授業に注目し、教師 主導の言語知識の伝授を主に受けてきた中国の日本語専攻生が、対話型授業をどの ように捉えているのかについて分析することを目的とする。具体的には、筆者が中国の 日本語専攻で行った卒業論文（以下、卒論）支援の実践に参加した学習者を調查対象 とし、彼らが教師一学習者間、学習者同士間の対話についてどう捉えていたか、そして、 教室内における教師一学習者間、学習者同士間の対話がどのように教室外に広がって いたかについて検討する。

\section{2. 教育における対話への関心}

教育パラダイムは、大きく捉えると、客観主義と構成主義に分かれる。久保田 (2000) は、この 2 つのパラダイムの特徵をまとめた。客観主義の前提は、知識を客観的に 把握できる実態として捉え、知識の置かれている状況から知識を分離した中で分析を 加えることで構造を解明することができるという信念である。客観主義の立場では、 学習者はもともと受動的であり、あまり有能ではないと見なされる。そのため、 効果的に知識を身につけるためには、まず教える人がいなくてはならないとされる。 一方、構成主義の立場では、知識は、人々の相互作用によって構築されるもので、 人間の個人的な体験、属する文化等と切り離すことができない、状況に依存するもの とされる。学習は、学習者自身が知識を構築していく過程で、共同体の中での相互 作用を通じて行われる。 
以上の 2 つの教育パラダイムに基づいて教育理論も大きく異なる。客観主義に 基づいた典型的な理論は、1960 年代に全盛を誇った行動主義心理学である。行動主義 的学習観について、佐伯（1998：5）は次のように概観している。学習は「頭の中」に 知識を体系的に貯蔵し、必要なとき過去に獲得した適切な知識を効率よく引き出せる ようにすることで、学習は「刺激」に対する「反応」の結びつきであって、「条件 付け」によって形成されるものとされた。一方、構成主義に基づく教育では、知識を 人々の相互作用によって構築されるとするため、学習も、共同体の中で知識を構築 していく過程と捉えられる。そこで、「対話」が、キーワードとなっている。佐藤 (1995) は、従来の教育で目指された「学習」、「勉強」という概念と対置して「学び」を 提案し、学びの実践を「語りを通して意味を構成し、その意味の語りを通して関係を 構築する」（p.73）とする。そこで、対話的学びの三位一体論、つまり、自分と対象、 自分と自己、自分と他者との関係における対話的学びを提起している。

日本語教育は、客観主義から構成主義に転換しつつある教育理論と同じ流れを受け 継いでいる。日本語教育において、行動主義心理学をもとに開発されたオーディオ・ リンガル・メソッドは、文法積み上げ方式が取られ、文型練習が中心になっていた。 認知心理学をもとに開発されたコミュニカティブ・アプローチは、コミュニケーション 能力の育成を中心とし、情報の格差を埋めることがコミュニケーションの本質である と規定されている。しかし、認知心理学に基づいて開発されたコミュニカティブ・ アプローチも、「習得す心゙き言語知識や言語技能というものがあって、それを学習者 に身につけさせるための手段」（西口 1999 : 14）であるため、客観主義の教育理論 から脱却していない。そして、1990年代半ば以降、客観主義的パラダイムから「自律」 と「協働」に特徵付けられる構成主義的パラダイムにヘシフトされた（佐々木 2006）。 近年、対話に基づいた日本語教育実践が日本で広がり、多く報告されている（蔭山2016）。 その一方、日本国外の日本語教育における対話型授業の実践は試みられているものの （三代 2006、李 2016 など）、まだ少数であり、伝統的な客観主義の教育を主に受けて きた日本国外の日本語学習者は対話型授業をどのように捉えているのかについての 詳細な研究は見当たらない。

\section{3. 中国における日本語専攻教育の問題点}

中国における日本語専攻教育には、依然として教師主導による言語知識の伝授と いった傾向が強い。まず、日本語専攻教育の大綱（「学習指導要領」に相当）を見て みよう。日本語専攻教育の大綱は、初級段階と上級段階という 2 つに分かれており、 日本語専攻教育の目標、内容などを規定している。2つの大綱とも、その根底に見られる 教育観が批判されている。例えば、葛（2012）は、日本語専攻教育の大綱について、 「学生が「学ぶ」ことより、教師が「教える」ことに重点が置かれ、いかに正しく、 


\section{日本語専攻生の対話型授業に対する捉え方 一中国の大学日本語専攻で行われた卒業論文支援の実践分析から一}

効率的に教えるべきかが丹念に記述、規定されており、「知識の伝授者」としての教 師の主導的な立場が強調されている」（p.41）とし、「簡単にまとめると教室を中心と する、教師主導による知識注入型の教育観が根底にある」（p.40）と述べている。

次に、コマ数が最も多い主要科目である精読授業について述べる。精読授業から、 日本語専攻教育における教師主導、そして、言語知識重視の強い傾向がよくわかる。 冷（2005）は、精読授業の中心的な活動は、文法の説明、本文の説明、単語の説明と なっているため、言語の運用能力よりも、言語知識を重視する傾向にあると指摘して いる。そして、このような精読授業は、創造性の高いコミュニケーション練習が 行われていない場合が多いと述べている。また、田中（2014）は、同じ作品を掲載 している日本の国語教科書と日本語専攻の精読授業の教科書における設問項目について 分析し、国語教科書に「他者との意見交換」についての設問が比較的に多いものの、 精読授業の教科書にほとんど見られないと指摘した。

最後に、本研究で取り扱う卒論と深くかかわる作文授業について述べる。張・陳 （2004）では、作文授業を担当する教師に対する調査を分析した。その結果、伝統の、 言語形式を重視し、内容を軽視するプロダクトアプローチは、依然として作文授業を 支配していることが見えてきた。作文授業は、習った文法、語彙の運用と復習になって しまっているという。そして、鳥井他（2010）がまとめた従来の作文授業の流れは、 次のようになっている。まず教師が文法、語彙、文章構成などの指導を行い、その後 学習者に課題作文を提示する。次に学習者は課題作文（200～400 字程度）の計画を 立て、その後作文を授業時間内に書く。学習者が作文を書き終えると、教師は作文を 回収し、添削した後に学習者に返却する。学習者は、教師やほかの学習者との間に 対話を行っていない。これらの先行研究の指摘から、多くの作文授業は、言語形式に 重点を置き、日本語知識の学習、書くスキルの訓練になっていることがわかる。

以上、中国の大学における日本語専攻教育の大綱、精読授業、作文授業について まとめた。その結果、大綱から見られる教育観は、教師主導による知識注入型の 教育観にあること、そして、精読授業は、言語知識の伝授が中心になっていること、 多くの作文授業は、言語形式に重点を置かれ、文法、語彙の運用と復習になっている ことがうかがえてきた。教師主導の知識伝授が教室を支配することになると、思考力 育成に必要な能動性の発揮、他者との対話が実現できなくなってしまい、学習者の 思考力が弱いという結果につながる。実際に、中国における日本語専攻生は、思考力が 弱いという批判が先行研究でなされている。例えば、中国の日本語専攻教育を概観 した譚（2009）は、日本語専攻生は、「ほかの文系学生と比べて、思考の論理性、 条理性が比較的弱く、知識の構成が比較的狭く、研究力が比較的弱い。巨視的な思考 と人文素質が欠ける。」（p.244）と指摘している。 


\section{4. 卒論支援の概要}

本研究では、筆者が 2010 年 12 月から 2011 年 6 月までに中国のある大学の日本語 専攻で行った卒論支援の実践を調査フィールドにした。本節では、実践の概要に ついて、卒論支援のデザイン、卒論支援のスケジュール、卒論支援における対話の 特徴に分けて説明する。

\section{1 卒論支援のデザイン}

中国の大学日本語専攻教育においては卒論が重視されている。上級段階の大綱 （中国教育部高等学校外語専業教学指導委員会日語組 2000）では「一般的に、学生は、 卒業するまでに卒業論文を書かなければならない」（pp.7-8）こと、そして「基本的には 日本語で執筆する」（p.8）ことが明記されている。大学によって、卒論に与えられた 単位が異なるが、本実践が行われる大学では、6 単位も与えている。

卒論指導の形式は個人主導が主流になっており、対話形式のゼミナールが行われて ない。前述した教師主導による言語知識の伝授という傾向を変え、学習者の問題発見・ 問題解決する思考力、他者と意思疎通を行い、新しい意味を創出する表現力を育む ためには、対話型授業が必要になる。そこで、前掲した佐藤（1995）が提示する、 学習者が学ぶ対象との対話、自己との対話、他者との対話、からなる三位一体の対話 的実践の実現を目指して、教室内の他者との対話を中心に展開するように、卒論支援 の活動をデザインした。なお、日本語教育の分野において三位一体の対話的実践を 提示した池田・舘岡（2007）は、学習者同士のピア・ラーニングの観点で「他者」を 「仲間の学習者」と表現しているが、教師は介入や促しで対話に参加することについても 述べている。本研究では、仲間の学習者だけではなく、教師、ボランティアも含め 「他者との対話」とする。

\section{2 卒論支援のスケジュール}

卒論支援は、2つのグループ（G1 と G2）に分けて行った。1つのグループは、学習 者 3 名（G1：W、H、L ）か 2 名（G2：Li、R）、教師 2 名、ボランティア 1 名の 構成である。全員、中国語母語話者である。学習者は、対話型授業に参加するのが 初めてである。筆者は、2 グループの活動ともに教師として参加していた。

支援活動は、それぞれのグループで 22 回実施された。毎回の支援活動の時間は、 3 名の学習者がいる G1 は 90 分程度で、2 名の学習者がいる G2 は 60 分程度であった。 支援活動で使用する言語については、一部の課題を除き、日本語を使うか、母語を 使うか、学習者自身の判断に任せた。支援活動のスケジュールは、表 1 の通りになる。 支援活動の主要な活動は、課題論文の読みについて話し合う「読みの検討」活動、 
学習者のテーマについて話し合う「テーマの検討」活動、研究の具体的な展開について 話し合う「研究全般の検討」活動、アカデミック・ライティングというジャンルの「約束事」 になる「引用」、「文体」、「パラグラフ・ライティング」などについて発表し、 話し合う「表現項目の発表」活動である。そのほかに、「ガイダンス」では、支援 活動の目標、構成、評価方法、「事前課題」への要求、言語使用への要求などについて 説明した。また、前期と後期の最終回において、それぞれ目標に沿って自己評価をし、 自由に他者評価をする「相互・自己評価会」を行った。

表 1 : 支援活動のスケジュール

\begin{tabular}{|c|c|c|c|}
\hline 週 & 支援活動を構成する各活動 & \multicolumn{2}{|c|}{ 事前課題 } \\
\hline 1 & ガイダンス & \multicolumn{2}{|l|}{-} \\
\hline \multirow{2}{*}{$2 \sim 7$} & 読みの検討 & タスクシート & \multirow{6}{*}{$\begin{array}{l}\text { 振り } \\
\text { 返り } \\
\text { シート }\end{array}$} \\
\hline & テーマの検討 & - & \\
\hline 8 & 相互・自己評価会 & - & \\
\hline \multirow{3}{*}{$9 \sim 20$} & 研究全般の検討 & 発表レジュメ & \\
\hline & 表現項目の発表 & 表現項目まとめ & \\
\hline & （10１6 週） & のレジュメ & \\
\hline 21 & 口頭発表の練習 & \multicolumn{2}{|c|}{ 卒論、発表資料 } \\
\hline 22 & 相互 $\cdot$ 自己評価会 & \multicolumn{2}{|l|}{-} \\
\hline
\end{tabular}

\section{3 卒論支援における対話の特徵}

支援活動における対話の特徵を見るために、9 週目、16 週目、18 週目の活動の録音 記録を文字に起こした資料を分析した。この3 回の支援活動には、参加する教師が 1 人の場合（9 週目に教師 $\mathrm{T} 1$ が久席）と 2 人の場合、使用言語が日本語の場合と 中国語の場合が含まれ、比較的教室内の話し合いの特徴が見えると考え、分析の対象 にしたのである。分析したのは、録音記録の文字化資料における各メンバーの発話数、

及び、教師が教室内の話し合いを促す発話のパターンとその発話数である。その結果を 次の表 2 と表 3 に示した。なお、表 2 の縦軸は、中心の学習者（研究内容が中心に 検討される学習者）を示しており、横軸はそれぞれのメンバーを示している。数字は、 発話数とすべての発話数に占める割合である。

まず、教師一学習者間のやり取りが多いという特徵が浮き彫りになった。表 3 に 示している 3 回の活動における平均の発話数を見てみると、中心の学習者と教師 (教師 2 名の合計) 間の発話数（グレー）は、学習者W、学習者 L、学習者 Hの場合、 それぞれ 35\%と 54\%、34\%と 54\%、36\%と 57\%であり、合計したらどれも全発話の約 9 割を占めていた。教師一学習者間のやり取りは、支援活動に大きく影響していたことが 
推測される。一方、中心の学習者以外の学習者による発話を合計すると、学習者W、

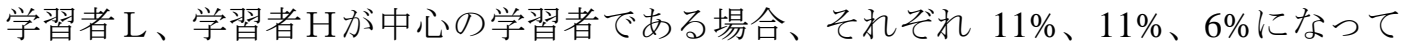
いる。学習者同士間の対話が行われたが、その比率はあまり高くなかった。

表 2 : 支援活動におけるメンバーの発話数

\begin{tabular}{|c|c|c|c|c|c|c|c|}
\hline \multicolumn{2}{|c|}{ 中心の学習者 } & $\mathrm{W}$ & $\mathrm{L}$ & $\mathrm{H}$ & 教師 1 & 教師 2 & $\begin{array}{l}\text { ボラン } \\
\text { ティア }\end{array}$ \\
\hline \multirow{5}{*}{ W } & 9 週目 & $27(39 \%)$ & $9(13 \%)$ & $5(7 \%)$ & & $28(40 \%)$ & $1(1 \%)$ \\
\hline & 16 週目 & 64(34\%) & $6(3 \%)$ & $8(4 \%)$ & $40(21 \%)$ & $70(37 \%)$ & 0 \\
\hline & 18 週目 & $84(34 \%)$ & $5(2 \%)$ & $21(9 \%)$ & $96(38 \%)$ & $39(16 \%)$ & $2(1 \%)$ \\
\hline & \multirow{2}{*}{ 平均 } & \multirow{2}{*}{$\begin{array}{l}175 \\
(35 \%) \\
\end{array}$} & \multirow{2}{*}{$20(4 \%)$} & \multirow{2}{*}{$34(7 \%)$} & $136(27 \%)$ & $137(27 \%)$ & \multirow{2}{*}{$3(1 \%)$} \\
\hline & & & & & \multicolumn{2}{|l|}{$273(54 \%)$} & \\
\hline \multirow{5}{*}{$\mathrm{L}$} & 9 週目 & $12(14 \%)$ & $32(38 \%)$ & $6(7 \%)$ & & 33(39\%) & $2(2 \%)$ \\
\hline & 16 週目 & $1(1 \%)$ & $44(41 \%)$ & $2(2 \%)$ & $28(26 \%)$ & $33(31 \%)$ & 0 \\
\hline & 18 週目 & $5(3 \%)$ & $41(27 \%)$ & $14(9 \%)$ & $58(38 \%)$ & $36(23 \%)$ & 0 \\
\hline & \multirow{2}{*}{ 平均 } & \multirow{2}{*}{ 18(5\%) } & \multirow{2}{*}{$\begin{array}{l}117 \\
(34 \%) \\
\end{array}$} & \multirow{2}{*}{$22(6 \%)$} & $86(25 \%)$ & $102(29 \%)$ & \multirow{2}{*}{$2(1 \%)$} \\
\hline & & & & & \multicolumn{2}{|l|}{$188(54 \%)$} & \\
\hline \multirow{5}{*}{$\mathrm{H}$} & 9 週目 & $1(2 \%)$ & 0 & $30(46 \%)$ & & $32(49 \%)$ & $2(3 \%)$ \\
\hline & 16 週目 & 0 & 0 & $32(43 \%)$ & $29(39 \%)$ & $14(19 \%)$ & 0 \\
\hline & 18 週目 & $11(6 \%)$ & $6(3 \%)$ & $55(30 \%)$ & $63(34 \%)$ & $49(27 \%)$ & 0 \\
\hline & \multirow{2}{*}{ 平均 } & \multirow{2}{*}{$12(4 \%)$} & \multirow{2}{*}{$6(2 \%)$} & \multirow{2}{*}{$\begin{array}{l}117 \\
(36 \%) \\
\end{array}$} & $92(28 \%)$ & $95(29 \%)$ & \multirow{2}{*}{$2(1 \%)$} \\
\hline & & & & & \multicolumn{2}{|l|}{$187(57 \%)$} & \\
\hline \multicolumn{2}{|c|}{ 合計 } & $205(17 \%)$ & $143(12 \%)$ & $173(15 \%)$ & $314(27 \%)$ & $334(28 \%)$ & $7(1 \%)$ \\
\hline
\end{tabular}

表 3 : 教師が教室内の対話を促す発話の数

\begin{tabular}{|c|c|c|c|c|}
\hline 発話パターン & $\mathbf{9}$ 週目 & $\mathbf{1 6}$ 週目 & $\mathbf{1 8}$ 週目 & 平均 \\
\hline $\begin{array}{c}\text { 全員に向けて促す発話 } \\
\text { (例えば、「ほかにありますか」) }\end{array}$ & 6 & 4 & 8 & 6 \\
\hline $\begin{array}{c}\text { 学習者、ボランティアを指定する場合 } \\
\text { (例えば、「○さんはどう思いますか」) }\end{array}$ & 2 & 1 & 4 & 2.3 \\
\hline
\end{tabular}

2つ目の特徵は、教師は教室内の話し合いを促す質問をし、教室内の話し合いを活性 化させたケースが多く見られることである。この特徵は、まず発話数から確認できる。 
表 3 で示した通り、教師は、1 回の活動で、「ほかにありますか」などのような全員に 向けて促す発話を平均で 6 回行っていた。「○さんはどう思いますか」のような、 特定のメンバーの発言を促す発話を平均で 2.3 回行っていた。一回の活動で、教室内の 対話を促す発話は、平均で 8.3 回行われていた。次に、教室内の話し合いの資料からも、 教師の促しによって、教室のメンバーが活発に各自の意見を述心゙、研究についての 理解が深められている特徵が確認できた。資料 1 は、18 週目に行われた学習者Lの 下書きを検討する際の話し合いの一部である。学習者Lは、一部の大学生が持って いる「日本人は変態だ」1というイメージについて調査し、この日に分析結果をまとめた 卒論の下書きを教室に持ってきた。学習者 L の発表後に沈黙に陥ったメンバーに、 教師 T1 は、「ほかにありますか」とグループメンバーの発言を促した（01）。そう すると、学習者Wは、学習者Lの書き方で、重複すると思われる部分を指摘した (02)。 学習者 Hは、学習者 Lの分析がまだ深くないと指摘し、「日本人は変態だ」という イメージの形成原因は、日本人を知るルートにあるのではなく、「中国人の考え方に ある」という考え方を示した。この考え方をめぐって、学習者Lと学習者Hは、さらに 人を知るルートがイメージ形成に与える影響について話し合った（04～09）。教師 T2 は、二人の話し合いをまとめ、文化的差異、心理学の分析視点が必要で、キーワード である「変態」の定義を再度学習者 Lに求めた（10）。

\title{
資料 1 ：学習者 Lの下書きを検討する話し合い（G1、18 週目）（筆者訳）
}

\begin{abstract}
01T1ほかにありますか。
$02 \mathrm{~W}$ 表（筆者注：学習者 L のレジュメにある表）の中の 5 点の結果と、最後の 「変態だと思う表現の分析」の部分とは重複していませんか? 前では事実 だけを挙げて、後で具体的に分析するという感じですか。

$03 \mathrm{~L}$ そうです。(中略) 自分でも、このような書き方は初めて読む人から重複 しているように見られるかわからず、書き方をどうするか迷いました。

$04 \mathrm{H} \quad 2.3$ 節の、「中国大学生は日本人は変態だと思う原因はどこにあるか」に ついての分析はまだ梁くないと思います。この分析（筆者注：2.3 節には、 日本人についての情報を得るルートがまとめられている）を見ると、日本 を知り、日本人は変態だと思うようになるというような印象を受けました が。
\end{abstract}

元来、これは差別的な言説ではあるが、学習者 L は 2 週目の振り返りシートで「本当の 日本がどのような国ですか、私たちはどのような態度をもってその国を新たに見直すか、 知れたものを皆さんに伝えることが日本語学習者としている自分の責任だと思います」と 書いていたため、担当教師として、学習者 L の研究動機を認めることにした。そして、 最後に、学習者 L は卒論において、日本人が「変態」であるというイメージの形成は、 主観的な考えの影響を受けていると考えられ、日本人と日本文化を理性的な視点で見るべき だと主張していた。 
$05 \mathrm{~L} こ の$ 分析は、今持っている知識で原因を分析したかったのですが、私の 考えを支持してくれる先行研究が見つからなくて。

$06 \mathrm{H}$ 日本人は変態だと思う原因は、日本人を知るルートにあるじゃなくて、 これらのルートを経由して日本人を知って、われわれの生活習慣にない ことを、日常の慣習や伝統から逸脱していると思って、日本人は変態だ と思うようになっていますよね。だから、その原因は、中国人の考え方に あると思います。（後略）

$07 \mathrm{~L}$ 例を挙げましょう。例えば、2 人は電話をしている。 $\mathrm{A}$ は 9 と言った つもりだけど、Bには 10 だと聞こえました。原因は、Aが言い間違えたか、 Bが聞き間違えたか、電話が故障しているかの 3 つですね。だから、今 話した電話の例ように、ルートにも原因があるのかもしれないですね。

08H というのは、放送されたときはすでに現実と違うということですか? 一方は、日本人の理解の仕方、一方は中国人の理解の仕方。

$09 \mathrm{~L}$ 皆さんは日本をフィルターをかけてみていますよね。ある人は、度のない めがねをかけてみて、きれいに見えているかもしれない。ある人は、凹凸 鏡を通してみて、歪んでいるように見えるかもしれないですね。

10T2 お二人が言っていることは、実は同じですね。どのような立場でこれを 見ているかという文化背景の問題に帰結できますね。前から原因には いくつかの側面があると言ったでしょう。「変態」の定義をまず明確にして くださいと 2 回も言いましたよ。今日の議論を通して、最後に「変態」が 成り立つかを検討し、その原因を分析するとき、定義はやはり欠かせない と思います。 $\mathrm{H}$ さんが言った文化的差異が、1つの分析のための視点です ね。(中略) もう1つは心理学の視点ですね。つまり、心理学の理論で「変 態」を限定する必要がありますね。(後略)

\section{5. 分析結果 : 対話型授業に対する学習者の捉え方}

本節では、分析資料を説明したうえ、分析結果を「教師一学習者間の対話に対する 学習者の捉え方」、「学習者同士間の対話に対する学習者の捉え方」、「教室内に おける対話の広がり」に分けて述べる。

\section{1 分析資料}

分析の際に、分析の観点によって、具体的に以下のような資料を用いた。まず、 「教師一学習者間の対話に対する学習者の捉え方」に関して、支援活動後に学習者を 対象としたアンケート調査（中国語）の記述を中心に分析した。それに加え、22週目 に行った支援活動「相互・自己評価会」と 13 週目に行った支援活動途中のインタビュー (中国語) で学習者が語ったエピソードを挙げた。次に、「学習者同士間の対話に対する 学習者の捉え方」に関しては、前述した「相互・自己評価会」（22 週目）における 学習者の語りを分析した。最後に、「教室内における対話の広がり」に関しては、 
支援活動の録音記録の文字化資料、支援活動途中のインタビュー（13 週目、中国語）、 及び、支援活動終了 1 年後の追跡調査（中国語）結果から、学習者が語ったエピソード をピックアップして分析を行った。

\section{2 教師一学習者間の対話に対する学習者の捉え方}

学習者は、教師と学習者は対等な関係にあり、教師を傾聴者、アドバイザーと捉えて いた。次の表 4 に示しているのは、支援活動後のアンケート調査の中で、「活動に おける教師と学生の関係性についてどう思いますか」に対する学習者の回答である。 5 名中の 3 名の学習者は、教師との間では対等な関係であると捉えた。学習者W、 学習者 $\mathrm{H}$ 、学習者 Li は、教師とは（比較的）対等な関係であり、「自分の考え」、 教師と「違う意見」が言え、そして、積極的に教師に「助けを求める」こともでき、 活動の時間を「居心地よく過ごせた」と言った。そして、ほかの 2 名の学習者は、 「対等」とは言わなかったが、プラスイメージを持っていた。学習者 Rは、支援活動に おける教師と学習者は従来の指導一被指導の関係ではなく、「仲良」い関係だったと 捉え、教師は、学習者の「意見と見方を十分に尊重」し、「事例で啓発し、間違いは どこにあるか、どこを改善すべきかを気づかせ」る「傾聴者」と「アドバイザー」で あると言った。そして、学習者Lは、支援活動における教師は「学生の指導を重視」し、 学習者は「積極的に教師の指導に応えよう」とし、「双方の交流がよくできた」と 語っていた。

\section{表 4 : 支援活動後の調査における学習者の回答}

\begin{tabular}{|c|c|}
\hline 学習者 & 学習者の回答（筆者訳） \\
\hline W & $\begin{array}{l}\text { 教師と学生の間では対等の関係になっていると思う。この対等な関係の下、先生と } \\
\text { 違う意見も大胆に言えていた。 }\end{array}$ \\
\hline $\mathrm{L}$ & $\begin{array}{l}\text { 先生たちは学生の指導を重視し、学生は積極的に教師の指導に応えようとする。 } \\
\text { 双方の交流がよくできたと思う。 }\end{array}$ \\
\hline $\mathrm{H}$ & $\begin{array}{l}\mathrm{T} 1 \text { 先生は最初から私たちとの交流は対等であると強調した。それが、皆が大胆に } \\
\text { 自分の意見を言うという方に働いたと思う。私は先生との間は、わりと対等な関係 } \\
\text { だったと思う。 }\end{array}$ \\
\hline $\mathrm{Li}$ & $\begin{array}{l}\text { 先生との対等な関係が、（筆者補足：活動の時間を）居心地よく過ごせたことに } \\
\text { つがったと思うし、大胆に自分の考え方と意見を言い出せた。そして、困難に } \\
\text { 遭ったとき、積極的に先生に助けを求めることもできた。 }\end{array}$ \\
\hline $\mathrm{R}$ & $\begin{array}{l}\text { この活動において、先生と学生は仲良かったと思う。先生は、強い立場ではなく、 } \\
\text { 私たちの傾聴者とアドバイザーになって、私たちの意見と見方を十分に尊重して } \\
\text { くれた。間違ったときでも、先生はすぐに否定し、自分の意見を押し付けることなく、 } \\
\text { 事例で啓発し、間違いはどこにあるか、どこを改善すべきかを気づかせてくれた。 }\end{array}$ \\
\hline
\end{tabular}


また、学習者は決して教師から言われたことをそのまま受け入れたわけではなく、 教師の話を批判的に吟味していた。例えば、学習者Wに、教師からのアドバイスを 吟味してから、それに従ったというエピソードがある。学習者Wは「相互・自己評価会」 （22 週目）で、自分の研究について、教師からアドバイスをもらったが、そのアドバイス を受け入れるのに 3 週間かかったという話をし、「納得して採用したが、納得でき なかったら採用しなかった」と言い、教師のアドバイスを吟味する過程について振り 返った。また、学習者 Li も、13 週目に行われた支援活動途中のインタビューでは、 次のように教師による書面フィードバックに対して批判的に読む意識が生まれたと 言った。

前は、先生のフィードバックを見れば、直さなければと思いました。2 週間前から、 私自身にも自分なりの考えを持っているはずで、先生の意見は参考のために 過ぎず、私は先生の意見を参考にするけれども、先生も私の考えを参考にする ことがあるかもしれないと思うようになりました。（筆者訳）

\section{3 学習者同士間の対話に対する学習者の捉え方}

支援活動は、学習者の仲間と対話する意識が芽生える場にもなった。学習者同士 間の対話は多くないものの、確実に行われていた（本文の第 4.3 節を参照）。学習者の 振り返りから、学習者は、仲間との対話が不足していると反省し、仲間の意見が大事 であると考えていたことがうかがえた。22 週目に行われた「相互・自己評価会」で、 学習者 L と学習者Wは、仲間との対話の不足について反省していた。学習者 L は、 ほかの仲間の論文をきちんと読んでおらず、理解が浅かったため、積極的に交流でき なかったことを反省していると言った。学習者Wは、ほかの学習者の対話への積極的 な参加を評価しつつ、自分の対話への参加について次のように振り返り、「自分には ほかの人に意見を言う資格がない」という自分の考え方を反省し、「仲間の意見が とても大事だ」という認識を示した。

最後に自分の力不足について反省します。活動というのは、1人の研究について、 先生とほかの人がコメントするものだと理解しています。でも、自分の中には、 発表者ほどそれについて知らないのに、発表者も考えていないことを自分が考え られるのか、自分の意見が余計なものではないかという思いがあって、自分には ほかの人に意見を言う資格がないのだと思っていました。でも、そうではないの です。私の基準（筆者注 : 教科書の中の外来語を評価するための基準）は、Lさん のコメントからヒントを得て決められたのです。仲間の意見がとても大事だと 思います。（筆者訳） 


\section{4 教室内における対話の広がり}

教室内の教師一学習者間、学習者同士間の対話は、やり取りを直接する者の間に、 そして、教室内にとどまることなく、対話に直接参加しなかった教室内のほかの学習 者にも影響を与え、学習者の教室外における他者との対話を活性化させた。さらに、 修了した学習者の社会生活にもよい影響をもたらした。

まず、教室内の教師一学習者間の対話は、対話に直接参加しなかったほかの学習者 にも示唆を与えていた点について述べる。この点に関しては、学習者 Li の 2 つ事例 が挙げられる。第 5 週目に、学習者 Li はが研究テーマを探すために自分と「日本」の 関わりを振り返って整理した。その行為は、前の週の支援活動からの影響と見られる （4 週目、5 週目の支援活動の記録より）。前の週の支援活動で、「自分の興味・関心は どこにあるか分からない」と言っていた同グループの学習者 Rのために、皆で学習者 $\mathrm{R}$ の興味・関心、得意な科目、できそうな研究分野について話し合っていた。それに 触発されたように、テーマで悩んでいた学習者 Li も、自分と「日本」の関わりを自主 的に振り返った。また、学習者 Li は、映画を分析したが、その結果を量的に表現 することがうまくいかなかったとき、支援活動で学習者 Rが作った表を見て「お一、 と思って、うれしかった」（筆者訳）と言い、学習者Rの研究方法に影響を受けていた （16 週目の支援活動の記録より）。

また、教室内の教師と学習者間の対話は、学習者の教室外における他者との対話を も活性化させていた。次に挙げる 2 つ事例は、支援活動途中のインタビュー（13 週 目）で学習者が語ったものである。学習者Hは、クラスメートに研究計画書を見る ことを頼まれ、教師のような視点で、頼んだ人と話し合ったことが何回もあったと 言った。また、学習者 Rは、次のようなエピソードを語った。学習者 Rは、教室内の 話し合いで、「じいちゃんは外面がいいから、看護婦さんにはいい顔を見せるのに、 私には、鬼のように当たったのよ」という例文にある「外面」を、「がいめん」と 読み、「顔」と翻訳したら、教師に指摘され、辞書で調べ、自分が間違ったことを 確認した。「それ以来、間違いを避けるために、分析結果をルームメートにも見て もらって話し合っていた。」（筆者訳）と学習者Rは言った。

さらに、教室における対話は、学習者の卒業後の社会生活に活かされることも確認 できた。この点について、支援活動終了 1 年後の追跡調査での学習者 L の回答から 示唆される。学習者Lは、「今の仕事も卒論と同じようにグループの形で行われて いる。十分な情報交換、上司への早急な報告、ほかのメンバーの進捗や需要について の把握などは、話し合いによってしなければならない。」と言った。学習者Li の語り から、教室における対話は、学習者の社会生活で活かされる良い経験となっていた ことがうかがえる。 


\section{6. まとめと今後の課題}

以上、筆者が中国の大学で行った卒論支援の実践に参加した 5 名の日本語専攻生を 対象に、彼らが対話型授業をどのように捉えていたかについて分析した。日本語 専攻生は、教師主導による言語知識の伝授を主に受けてきて、対話型授業に対して 抵抗感が強いと思われているが、本研究では、日本語専攻生は対話型授業に対して 好感を持ち、対話型授業を受け入れる可能性を示せた。

一方、本研究の課題も残されている。本研究は、筆者が行った卒論支援の実践を フィールドにした基礎的・探索的な研究である。調査や授業記録が比較的詳しい反面 に、調查対象は 5 名に留まっている。対話型授業に対する学習者の捉え方をより総合 的に把握するために、調查対象者の人数を増やし、調查対象者の日本語レベル、これ までの学習歴などの多様性を考慮したうえで積み重祃る重亦て検証していくべきだと 考えられる。 


\section{日本語専攻生の対話型授業に対する捉え方 \\ 一中国の大学日本語専攻で行われた卒業論文支援の実践分析から一}

\section{参考文献}

池田玲子・舘岡洋子（2007）『ピア・ラーニング入門 創造的な学びのデザインのために』ひつじ 書房

蔭山拓（2016）「日本語教育における「対話」一対話主義的な第二言語教育の視点からの考察一」

『多文化社会と留学生交流』第 20 号,1-7

葛茜（2012）「中国の大学日本語専攻教育は何をめざしているか一『教学大綱』の分析から」

『日本語・日本学研究』第 2 号,33-44

久保田賢一（2000）『構成主義パラダイムと学習環境デザイン』関西大学出版部

佐伯胖（1998）「学びの転換一教育改革の原点」佐伯胖・佐藤学・浜田寿美男・黒崎勲・田中孝彦・

藤田英典『授業之学習の転換 現代の教育 3 』岩波書店, 3-24

佐々木倫子 (2006)「パラダイムシフト再考」国立国語研究所『日本語教育の新たな文脈一学習環境、

接触場面、コミュニケーションの多様性』アルク,259-283

佐藤学（1995）『学びの快楽ーダイアローグヘー』世織書房

田中祐輔（2014）「日本の国語教科書は中国の大学専攻日本語教育においてどのように用いられて

いるのか一教科書の設問に表れた指導内容の比較分析を中心に一」『文学・語学』第 210 号,26-38

鳥井俊祐・姜梅花・鐘俊梅（2010）「中国の大学生の日本語作文学習に関寸る Beliefs : 浙江樹人 大学のアンケート調査より」『日语学习与研究』6,59-65

西口光一（1999）「状況的学習論と新しい日本語教育の実践（境界をこえる日本語教育）」『日本語

教育』100,7-18

三代純平（2006）「韓国外国語高校における批判的日本語教育の試み」『リテラシーズ』第 2 号, 3-17 李暁博（2016）「「対話」の視点からみる学生の自己変容一中国の日本語教育の実践例をもとに」

『日本語日本文学』第 26 号,55-72

冷麗敏（2005）「中国の大学における「総合日本語（精読）に関する意識調査一学習者と教師の

回答を比較して」『日本言語文化研究会』創刊号,59-73

谭晶华（2009）「日语专业教育发展研究」戴炜栋・胡文仲『中国外语教育发展研究 1949-2009』

上海外语教育出版社,233-269

张静・陈俊森（2004）「日语写作教学法探讨:关于“任务教学法”和“结果教学法”的实证性研究」

『日语学习与研究』No.4,36-42

中国教育部高等学校外语专业教学指导委员会日语组 (2000)『高等院校日语专业高年级阶段教学大纲』 大连理工大学出版社

钟美称·孙有中 (2014) 「以人才培养为中心, 全面推进外语类专业教学改革与发展一第五届高等

学校外国语言文学类专业教学指导委员会工作思路」『外语界』No.1,2-8

\section{付記}

本研究は、中国広東省 2016 年度社科規划項目外語専項「情報化環境に置かれる 日本語専攻生の批判的思考力の育成：日本語アカデミック・ライティングにおける 文献レビューと文献引用を例に」（番号：GD16WXZ18、代表者 : 楊秀娥）の研究助成を いただきました。ここで感謝の意を表します。 